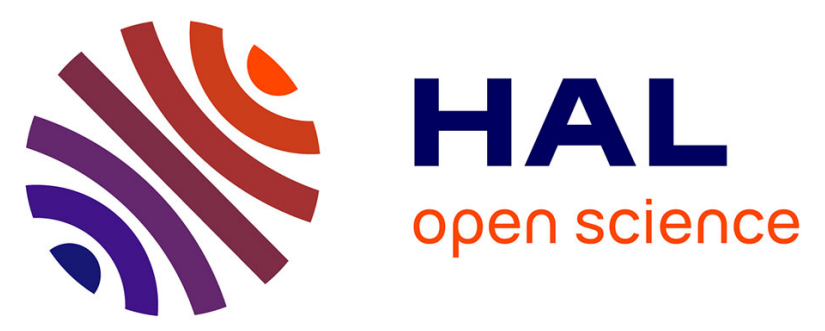

\title{
Comparison of the Transarterial and Transthoracic Approaches in Nontransfemoral Transcatheter Aortic Valve Implantation
}

Mathurin Beve, Vincent Auffret, Reda Belhaj Soulami, Jacques Tomasi, Amedeo Anselmi, Antoine Roisne, Dominique Boulmier, Marc Bedossa, Guillaume Leurent, Erwan Donal, et al.

\section{To cite this version:}

Mathurin Beve, Vincent Auffret, Reda Belhaj Soulami, Jacques Tomasi, Amedeo Anselmi, et al.. Comparison of the Transarterial and Transthoracic Approaches in Nontransfemoral Transcatheter Aortic Valve Implantation. American Journal of Cardiology, 2019, 123 (9), pp.1501-1509. 10.1016/j.amjcard.2019.01.040 . hal-02049700

\section{HAL Id: hal-02049700 \\ https://hal-univ-rennes1.archives-ouvertes.fr/hal-02049700}

Submitted on 18 Dec 2019

HAL is a multi-disciplinary open access archive for the deposit and dissemination of scientific research documents, whether they are published or not. The documents may come from teaching and research institutions in France or abroad, or from public or private research centers.
L'archive ouverte pluridisciplinaire HAL, est destinée au dépôt et à la diffusion de documents scientifiques de niveau recherche, publiés ou non, émanant des établissements d'enseignement et de recherche français ou étrangers, des laboratoires publics ou privés. 
Comparison Of The Transarterial And Transthoracic Approaches In NonTransfemoral Transcatheter Aortic Valve Implantation

Mathurin Beve, $\mathrm{MD}^{\mathrm{a},{ }^{*}}$, Vincent Auffret, $\mathrm{MD}^{\mathrm{a},{ }^{*}}$, Reda Belhaj Soulami, $\mathrm{MD}^{\mathrm{b}}$, Jacques Tomasi, $\mathrm{MD}^{\mathrm{b}}$, Amedeo Anselmi, MD PhD ${ }^{\mathrm{b}}$, Antoine Roisne, $\mathrm{MD}^{\mathrm{b}, \mathrm{c}}$, Dominique Boulmier, $\mathrm{MD}^{\mathrm{a}}$, Marc Bedossa, $\mathrm{MD}^{\mathrm{a}}$, Guillaume Leurent, $\mathrm{MD}^{\mathrm{a}}$, Erwan Donal, $\mathrm{MD} \mathrm{PhD}^{\mathrm{a}}$, Hervé Le Breton, $\mathrm{MD}^{\mathrm{a}}$, and Jean-Philippe Authors' affiliations: Verhoye, $\mathrm{MD} \mathrm{PhD}^{\mathrm{b}}$

a. University of Rennes 1,Cardiology and Vascular Diseases Department, Pontchaillou University Hospital, Signal and Image Treatment laboratory (LTSI), National Institute of Health and Medical Research U1099, Rennes, France.

b. University of Rennes 1, Cardiac, Thoracic, and Vascular Surgery Department, Pontchaillou University Hospital, Signal and Image Treatment laboratory (LTSI), National Institute of Health and Medical Research U1099, Rennes, France.

c. Anesthesiology Department, Pontchaillou University Hospital, Rennes, France.

* MB and VA equally contributed and should be considered co-first authors.

\section{FUNDING STATEMENT}

No extra-mural funding supported this work

\section{CONFLICT OF INTEREST STATEMENT}

Dr Vincent Auffret received research grants from Abbott, Edwards Lifescience, Medtronic, Biosensors, Terumo and Boston Scientific. Dr Le Breton received lecture fees from Edwards Lifesciences. The other authors have nothing to disclose.

\section{Corresponding author:}

Vincent Auffret, MD, MSc

Cardiology and Vascular Diseases Department

Pontchaillou University Hospital

2 rue Henri Le Guilloux, 35033 Rennes, France.

Phone: + 33299282 505, Fax: +33299282503

Email: vincent.auffret@chu-rennes.fr

\section{ABSTRACT}

Transfemoral approach stands as the reference access-route for transcatheter aortic valve implantation (TAVI). Nonetheless, alternatives approaches are still needed in a significant proportion of patients. This study aimed at comparing outcomes between transthoracic-approach (transapical or transaortic) and transarterial-approach (transcarotid or sub-clavian) TAVI. Data from 191 consecutive patients who underwent surgical-approach TAVI from May 2009 to September 2017 were analyzed. Patients were allocated in two groups according to the approach. The primary endpoint was the 30-day composite of death of any cause, need for open surgery, tamponade, stroke, major or life-threatening 
bleeding, stage 2 or 3 acute kidney injury, coronary obstruction, or major vascular complications. During the study period, 104 patients underwent transthoracic TAVI (transapical: 60.6\%, transaortic: 39.4\%) whereas 87 patients underwent transarterial TAVI (sub-clavian: $83.9 \%$, transcarotid: $16.1 \%$ ). Logistic EuroSCORE I tended to be higher among transthoracic-TAVI recipients. In-hospital and 30day composite endpoint rates were $25.0 \%$ and $11.5 \%(\mathrm{p}=0.025)$, and $26.0 \%$ and $14.9 \%(\mathrm{p}=0.075)$ for the transthoracic and transarterial cohorts, respectively. Propensity score-adjusted logistic regression demonstrated no significant detrimental association between the 30-day composite endpoint and transthoracic access (OR: 2.12 95\% CI: 0.70-6.42; p=0.18). Transarterial TAVI was associated with a shorter length of stay (median: 6 vs. 7 days, p<0.001). TAVI approach was not an independent predictor of mid-term mortality. In conclusion, non-transfemoral transarterial-approach TAVI is safe, feasible, and associated with comparable rates of major perioperative complications, and mid-term mortality compared with transthoracic-approach TAVI.

KEYWORDS: Aortic stenosis, Transcatheter aortic Valve implantation, Surgical approaches

Since the publication of the randomized Placement of Aortic Transcatheter Valves (PARTNER) trials ${ }^{1-3}$, transcatheter aortic valve implantation (TAVI) is recognized as an efficient therapy for treatment of severe aortic stenosis in inoperable, high and intermediate-risk patients. Transfemoral approach, as the Tess invasive and safest access, stands as the reference access route for TAVI. Although non-transfemoral approaches are decreasing with the miniaturization of delivery systems, in a recent national registry $17.2 \%$ of patients were still treated by non-transfemoral accesses $^{4}$. Alternative approaches requiring a surgical contribution include transaortic, transapical, sub-clavian, and, lately, transcarotid access. Transapical access is well-described ${ }^{5}$ and provides acceptable results. The transaortic approach requires to expose the ascending aorta using a ministernotomy or a right thoracotomy, and is associated with similar outcomes as transapical access ${ }^{6,7}$. Considering their invasiveness, the use of these transthoracic approaches is decreasing. Sub-clavian access is a safe method, showing comparable results to transfemoral approach ${ }^{8}$, however with the same limitations regarding vessel anatomy, and being unsuited for patients with thoracic artery grafts. Transcarotid access tends to represent a growing proportion of alternative accesses, despite 
ongoing questions regarding the risk of stroke $\mathrm{e}^{9,10}$. Given the paucity of direct comparisons of alternative accesses in the current literature, the aim of this study was to compare short and mid-term outcomes between patients undergoing transthoracic (transapical or transaortic) TAVI and transarterial (transcarotid or sub-clavian) TAVI.

\section{METHODS}

All patients who underwent a non-transfemoral approach TAVI at our institution (Rennes University Hospital, Rennes, France) from May 2009 to September 2017 were included. Details regarding the pre-procedural evaluation and follow-up modalities were previously published ${ }^{11}$. Details regarding the access selection process by the Heart Team are provided in the supplementary appendix. All patients gave written informed consent for the procedures and anonymous collection of their data, which were prospectively gathered in an electronic database. The institutional review board waived specific consent for this study due to its retrospective and observational nature.

Chronic lung disease was defined as a restrictive lung disease or a chronic obstructive pulmonary disease. Cerebrovascular disease was defined as a previous carotid surgery or a stenosis $\geq$ $50 \%$ of carotid or vertebral arteries. Peripheral artery disease included artery stenosis $\geq 50 \%$, claudication and previous vascular surgery. Surgical risk was estimated with the logistic EuroScore I, the logistic EuroScore II and the Society of Thoracic Surgeons Predicted Risk Of Mortality score. Valve Academic Research Consortium 2 (VARC-2) standards were used to define hostile chest, severe liver disease and all study endpoints ${ }^{12}$.

The primary endpoint was the 30-day rate of major perioperative complications defined as the composite of death of any cause, need for open surgery, tamponade, stroke, major or life-threatening bleeding, stage 2 or 3 acute kidney injury, coronary obstruction, or major vascular complications. Secondary endpoints were in-hospital and 30-day rates of the components of the primary endpoint and survival at follow-up.

Patients were included, according to the access site used, in the transthoracic (transapical or transaortic access) or transarterial (sub-clavian or transcarotid access) groups. Continuous variable are 
presented as mean \pm standard deviation or median (interquartile range) depending on their distribution, which was assessed using the Kolmogorov-Smirnov test, and were compared using $\mathrm{t}$ tests or the Mann-Whitney U test as appropriate. Categorical variables are summarized as numbers (percentages), and were compared using chi-square tests or the Fisher exact test. Survival rates were summarized using Kaplan-Meier estimates, and log-rank tests were used to compare groups. To evaluate the impact of access-site on the rate of the primary endpoint while adjusting for baseline differences between groups, propensity score-adjusted multivariable logistic regression was performed. Results are expressed as adjusted odds ratio (OR) with its $95 \%$ confidence interval (CI). The propensity score was calculated as the probability of undergoing transthoracic access using a non-parsimonious logistic regression model. Details regarding variables included in the propensity score can be found in the supplementary appendix. The propensity score model had adequate calibration (Hosmer-Lemeshow goodness-of-fit $\mathrm{p}=0.46$ ) and discrimination (c-statistic $=0.93,95 \% \mathrm{CI}$ : 0.89-0.97). Predictors of allcause mortality were analyzed using univariable and multivariable proportional hazard models (cumulative outcomes). The proportional hazard assumption was tested by plotting log-minus-log survival. Variables with p-values $<0.1$ in univariable analysis and the access-route were included in the multivariable analysis. Statistical analysis was performed with the use of Statistical Package for Social Sciences version 22 (SPSS, Chicago, IL, USA). All tests were 2-sided at the 0.05 significance level.

\section{RESULTS}

During the study period, 191 patients (female sex: 39\%) had a non-transfemoral approach TAVI, among which 87 patients (mean-age: $79.3 \pm 6.7$ years) underwent a transarterial approach and 104 patients (mean-age: $78.0 \pm 9.9$ years) a transthoracic approach. Sub-clavian access was performed in 73 patients $(38.2 \%)$, transcarotid in 14 patients $(7.3 \%)$, transaortic in 41 patients $(21.5 \%)$, and transapical in 63 patients (33.0\%). Supplemental Figures 1 and 2 show the annual number of each alternative access, and the annual proportion of all TAVI represented by each of these accesses. Baseline characteristics of the study population according to the approach are summarized in Table $\mathbf{1}$. Coronary artery disease was significantly more frequent in the transthoracic group than in the 
transarterial group ( $68.3 \%$ vs. $48.4 \%$; $\mathrm{p}=0.008)$. Patients of the transthoracic group harbored a higher burden of cerebrovascular disease $(18.4 \%$ vs. $3.4 \% ; \mathrm{p}=0.001)$ and hostile chest $(5.8 \%$ vs. $0.0 \%$; $\mathrm{p}=0.03$ ). Prevalence of peripheral artery disease was similar in both groups. Mean Logistic EuroScore I tended to be higher in patients treated with the transthoracic approach $(14.9 \%$ vs. $12.0 \%$; $=0.053)$. Echocardiographic parameters were similar between groups.

Procedural characteristics are described in Table 2. General anaesthesia was used in all transthoracic procedures, and in $90.8 \%$ of the transarterial ones $(\mathrm{p}=0.002)$. Balloon-expendable valves were much more frequently implanted in the transthoracic group $(96.2 \%$ vs. $26.4 \%$; $<<0.001)$. Device success was achieved in $95.2 \%$ of transthoracic TAVI recipients compared with $85.1 \%$ of their transarterial counterparts $(\mathrm{p}=0.024)$. Major intra-procedural complications were comparable between groups (Table 2).

In-hospital and 30-day outcomes of the 2 groups are depicted in Table 3. Supplemental

Tables 1 and 2 present a comparison of subclavian vs. transcarotid approaches, and transaortic vs. transapical approaches, respectively. In univariate analysis, the in-hospital composite endpoint rate was significantly higher in the transthoracic access cohort $(25.0 \%$ vs. $11.5 \%$; $=0.025)$, yet this difference did not persist at 30 -day (26.0 vs. $14.9 \%, \mathrm{p}=0.075)$. Propensity score-adjusted logistic regression confirmed the absence of a significant association between the 30-day composite endpoint and transthoracic access (OR: 2.12,95\% CI: 0.70-6.42; p=0.18). Albeit numerically higher in the transthoracic cohort, there was no significant difference between groups for in-hospital $(4.6 \%$ vs. 7.7\%; $\mathrm{p}=0.55$ ) and 30-days (4.6\% vs. $8.7 \% ; \mathrm{p}=0.39$ ) mortality. Also numerically higher in the transthoracic group, incidences of most major periprocedural complications were statistically comparable between groups. One contralateral transient ischemic attack occurred $24 \mathrm{~h}$ post-procedure in a patient who underwent left transcarotid TAVI under general anesthesia without balloon predilation. New-onset atrial fibrillation and acute kidney injury stage 2 or 3 were more prevalent in the transthoracic cohort. In the transthoracic access group, consistently with the lower use of selfexpendable valves, TAVI resulted in a lower rate of permanent pacemaker implantation than in the transarterial cohort. Length of hospitalization was higher ( 7.0 days vs. 6.0 days; $\mathrm{p}<0.001)$ and patients 
were less often discharged at home $(42.0 \%$ vs. $68.7 \% ; \mathrm{p}=0.002)$ in the transthoracic cohort. Echocardiographic findings at discharge are presented in Table 3.

Median follow-up was 395 days (interquartile range [IQR]: 320-974) and was significantly longer in the transthoracic cohort (676 days, IQR: 367-1182, vs. 367 days, IQR: 204-427; p<0.001). The 1-year Kaplan-Meier survival curves are shown in Figure 1. At 1 year, overall survival was similar in both groups (89.6\%; 95\% CI: 80.1-94.7 and 84.5\%; 95\% CI: 75.9-90.2 with the transarterial and transthoracic approach, respectively; $\mathrm{p}=0.30$ ). Figure 2 summarizes the multivariable predictors of all-cause mortality at follow-up. Atrial fibrillation (HR: 2.52; 95\% CI: $1.33-4.78$; $\mathrm{p}=0.005$ ), STSPROM score (HR: 1.18; 95\% CI: 1.01-1.39; p=0.04) and periprocedural stroke (HR: $5.85 ; 95 \%$ CI: 1.51-22.63; $\mathrm{p}=0.011$ ) were found as independent predictors of overall mortality. Transthoracic accessroute was not independently associated with mortality at follow-up (HR: 1.16; 95\% CI: 0.55-2.45; $\mathrm{p}=0.70)$

\section{DISCUSSION}

The main findings of this study are the following: despite a numerically lower incidence among transarterial TAVI patients, transthoracic approaches were not significantly associated with an increased rate of 30-days major perioperative adverse events or decreased mid-term survival (Figure 3). However, a shorter length of stay and a higher likelihood of being discharge at home were observed among transarterial TAVI recipients.

At the inception of the TAVI era, when a transfemoral approach was not feasible, a "transapical-first" policy was usually applied. Currently, strategies tend to evolve, with a priority for less invasive approaches. In a recent analysis of temporal trends in French registries ${ }^{4}$, transapical TAVI drastically decreased over time (from $27.9 \%$ in 2010 to $4.7 \%$ in 2015 among patients receiving a balloon-expandable valve). This evolution can be explained by an increase of transfemoral TAVI (73.4\% vs. $82.8 \%)$ and the expansion of alternative access-sites of more recent emergence such as the direct aortic, and, particularly, transcarotid routes $(5.5 \%$ and $3.4 \%$ of 12804 patients included in the FRANCE TAVI registry, respectively). Comparable findings were previously reported in the UK 
registry ${ }^{13}$. However, the transcarotid approach being the latest implemented in routine practice, the above-mentioned trend will likely accentuate regarding this specific access.

Transapical and transaortic TAVI are associated with similar rates of complications and comparable outcomes ${ }^{6,7}$. Our results regarding the in-hospital and 30-days morbidity and mortality of transthoracic TAVI are consistent with these recent studies. On the contrary to transthoracic TAVI, some groups reported favourable outcomes, sometimes comparable with the transfemoral approach, with the use of transcarotid and subclavian $\mathrm{TAVI}^{8,14,15}$. Therefore, these alternative transarterial accesses could conceivably be superior to transthoracic ones, and should represent the first option when transfemoral TAVI cannot be performed. However, the paucity of direct comparisons between non-transfemoral approaches supporting this assumption is highlighted by the observation that transthoracic access still represents the majority of alternative access TAVI in some regions, such as the US ${ }^{16}$. The present study adds to a small number of publications, which investigated the potential benefits of practicing a transarterial instead of a transthoracic approach ${ }^{9,17,18,19}$. As in the present study, a 3 Italian centers retrospective study also reported a non-significant trend to increased peri-procedural events, which did not impact mid-term survival, with the use of transapical versus subclavian TAVI ${ }^{18}$. Within the larger UK registry, Fröhlich et al demonstrated a significantly higher 2-year mortality following transapical or transaortic access than after transfemoral or subclavian TAVI ${ }^{17}$. Recently, using propensity score-matching, Chamandi et al published the largest comparative analysis specifically involving alternative access ${ }^{19}$. Ninety-four transcarotid TAVI recipients were matched with 163 transthoracie TAVI patients. Transcarotid access was associated with reduced 30-days rates of new-onset atrial fibrillation, major or life-threatening bleeding, stage 2 or 3 acute kidney injury, and a shorter length/ of stay. Mortality, stroke and device success were comparable between groups while early safety favored transcarotid access. The present study reports largely consistent findings.

Stroke was numerically higher in the transthoracic cohort, without significant difference between groups ( $3.8 \%$ vs. $1.1 \% ; \mathrm{p}=0.38$ ), which may be related to the small sample size. Beyond their heavier atherosclerotic burden, new-onset atrial fibrillation, a condition considerably more prevalent after transthoracic TAVR and associated with a higher risk of 30-days cerebrovascular events $^{20}$, may significantly contribute to an increased risk among recipients of this approach. This 
finding may be of paramount importance, as consistently with our results, periprocedural stroke was an independent predictor of mortality in previous studies ${ }^{21}$. Moreover, although local anesthesia was not consistently associated with better outcomes ${ }^{22}$, a higher rate of periprocedural stroke has been suggested with general anesthesia following transcarotid TAVI ${ }^{23}$. Only 50\% of transcarotid approach patients were treated under local anesthesia with sedation in the present study. Whether a broader use of local anesthesia and sedation with growing experience with this approach improves neurological outcomes should be the focus of future studies.

On the contrary, permanent pacemaker implantation was more frequent in the transarterialaccess cohort. As reported in previous studies ${ }^{24}$, this finding is related to the higher implantation rate of self-expandable valves in the transarterial group. With the expansion of TAVI to lower-surgical risk and younger patients, this result raises the major issue of potentially negative effects of long-term pacing, even if the impact of permanent pacemaker implantation after TAVI remains debated $\mathrm{d}^{24,25}$. However, during the early experience of TAVI, subclavian approach was almost exclusively performed with self-expandable valve. Yet, with growing experience, balloon-expandable valves are increasingly implanted through this access, which should mitigate its detrimental association with post-procedural pacemaker implantation.

Several limitations need to be acknowledged. First, there were significant differences in baseline characteristics between the two groups, which we attempted to adjust for by propensity scoreadjustment. Nonetheless, no statistical method can provide the degree of bias reduction obtained with randomization. Therefore, residual confounding, related to the higher burden of comorbidities observed in the transthoracic group, cannot be ruled out. Second, this is a retrospective analysis, based on a single center population with a limited number of patients in both cohorts, which implies a significant risk of type II error. Furthermore, because of the relatively recent development of this strategy in our center, the transcarotid approach was less represented than the subclavian access-route in the transarterial cohort. Considering the well-known learning-curve effect with other approaches ${ }^{26,27}$, we can hypothesized that our lower experience regarding transcarotid procedures in comparison with others approaches potentially influenced our results. Conversely, transcarotid TAVI was likely 
performed using more advanced valve technologies among patients with a lower surgical risk, which may have balanced our limited experience.

\section{CONCLUSION}

Non-transfemoral transarterial-approach TAVI is safe, feasible, and associated with comparable rates of major perioperative complications, and mid-term mortality compared with transthoracic-approach TAVI. Nonetheless, transarterial access may be associated with lower rates of new-onset atrial fibrillation, acute kidney injury, and shorter hospitalization.

\section{REFERENCES}

1. Leon MB, Smith CR, Mack M, Miller DC, Moses JW, Svensson LG, Tuzcu EM, Webb JG, Fontana GP, Makkar RR, Brown DL, Block PC, Guyton RA, Pichard AD, Bavaria JE, Herrmann HC, Douglas PS, Petersen JL, Akin JJ, Anderson WN, Wang D, Pocock S, PARTNER Trial Investigators.

Transcatheter aortic-valve implantation for aortic stenosis in patients who cannot undergo surgery. $N$ Engl J Med 2010;363:1597-1607.

2. Smith CR, Leon MB, Mack MJ, Miller DC, Moses JW, Svensson LG, Tuzcu EM, Webb JG, Fontana GP, Makkar RR, Williams M, Dewey T, Kapadia S, Babaliaros V, Thourani VH, Corso P, 
Pichard AD, Bavaria JE, Herrmann HC, Akin JJ, Anderson WN, Wang D, Pocock SJ, PARTNER

Trial Investigators. Transcatheter versus surgical aortic-valve replacement in high-risk patients. $N$ Engl J Med 2011;364:2187-2198.

3. Leon MB, Smith CR, Mack MJ, Makkar RR, Svensson LG, Kodali SK, Thourani VH, Tuzcu EM, Miller DC, Herrmann HC, Doshi D, Cohen DJ, Pichard AD, Kapadia S, Dewey T, Babaliaros V, Szeto WY, Williams MR, Kereiakes D, Zajarias A, Greason KL, Whisenant BK, Hodson RW, Moses JW, Trento A, Brown DL, Fearon WF, Pibarot P, Hahn RT, Jaber WA, Anderson WN, Alu MC, Webb JG. Transcatheter or Surgical Aortic-Valve Replacement in Intermediate-Risk Patients. $N$ Engl J Med 2016;374:1609-1620.

4. Auffret V, Lefevre T, Van Belle E, Eltchaninoff H, Iung B, Koning R, Motreff P, Leprince P, Verhoye JP, Manigold T, Souteyrand G, Boulmier D, Joly P, Pinaud F, Himbert D, Collet JP, Rioufol G, Ghostine S, Bar O, Dibie A, Champagnac D, Leroux L, Collet F, Teiger E, Darremont O, Folliguet T, Leclercq F, Lhermusier T, Olhmann P, Huret B, Lorgis L, Drogoul L, Bertrand B, Spaulding C, Quilliet L, Cuisset T, Delomez M, Beygui F, Claudel J-P, Hepp A, Jegou A, Gommeaux A, Mirode A, Christiaens L, Christophe C, Cassat C, Metz D, Mangin L, Isaaz K, Jacquemin L, et al. Temporal Trends in Transcatheter Aortic Valve Replacement in France: FRANCE 2 to FRANCE TAVI. $J$ Am Coll Cardiol 2017;70:42-55.

5. D’Onofrio A, Salizzoni S, Agrifoglio M, Cota L, Luzi G, Tartara PM, Cresce GD, Aiello M, Savini C, Cassese M, Cerillo A, Punta G, Cioni M, Gabbieri D, Zanchettin C, Agostinelli A, Mazzaro E, Di Gregorio O, Gatti G, Faggian G, Filippini C, Rinaldi M, Gerosa G. Medium term outcomes of transapical aortic valve implantation: results from the Italian Registry of Trans-Apical Aortic Valve Implantation. Ann Thorac Surg 2013;96:830-835.

6. Arai T, Romano M, Lefèvre T, Hovasse T, Farge A, Le Houerou D, Hayashida K, Watanabe Y, Garot P, Benamer H, Unterseeh T, Bouvier E, Morice M-C, Chevalier B. Direct Comparison of Feasibility and Safety of Transfemoral Versus Transaortic Versus Transapical Transcatheter Aortic Valve Replacement. JACC Cardiovasc Interv 2016;9:2320-2325. 
7. Thourani VH, Jensen HA, Babaliaros V, Suri R, Vemulapalli S, Dai D, Brennan JM, Rumsfeld J, Edwards F, Tuzcu EM, Svensson L, Szeto WY, Herrmann H, Kirtane AJ, Kodali S, Cohen DJ, Lerakis S, Devireddy C, Sarin E, Carroll J, Holmes D, Grover FL, Williams M, Maniar H, Shahian D, Mack M. Transapical and Transaortic Transcatheter Aortic Valve Replacement in the United States. Ann Thorac Surg 2015;100:1718-1726.

8. Gleason TG, Schindler JT, Hagberg RC, Deeb GM, Adams DH, Conte JV, Zorn GL, Hughes GC, Guo J, Popma JJ, Reardon MJ. Subclavian/Axillary Access for Self-Expanding Transcatheter Aortic Valve Replacement Renders Equivalent Outcomes as Transfemoral. Ann Thorac Surg 2018;105:477483.

9. Kirker EB, Hodson RW, Spinelli KJ, Korngold EC. The Carotid Artery as a Preferred Alternative Access Route for Transcatheter Aortic Valve Replacement. Ann Thorac Surg 2017;104:621-629.

10. Folliguet T, Laurent N, Bertram M, Zannis K, Elfarra M, Vanhuyse F, Maureira P, Modine T. Transcarotid transcatheter aortic valve implantation: multicentre experience in France. Eur J CardioThorac Surg 2018;53:157-161.

11. Auffret V, Boulmier D, Oger E, Bedossa M, Donal E, Laurent M, Sost G, Beneux X, Harmouche M, Verhoye J-P, Le Breton H. Predictors of 6-month poor clinical outcomes after transcatheter aortic valve implantation. Arch Cardiovasc Dis 2014;107:10-20.

12. Kappetein AP, Head SJ, Généreux P, Piazza N, Mieghem NM van, Blackstone EH, Brott TG, Cohen DJ, Cutlip DE, Es G-A van, Hahn RT, Kirtane AJ, Krucoff MW, Kodali S, Mack MJ, Mehran R, Rodés-Cabau J, Vranckx P, Webb JG, Windecker S, Serruys PW, Leon MB. Updated standardized endpoint definitions for transcatheter aortic valve implantation: the Valve Academic Research Consortium-2 consensus document. Eur Heart J 2012;33:2403-2418.

13. Ludman PF, Moat N, Belder MA de, Blackman DJ, Duncan A, Banya W, MacCarthy PA, Cunningham D, Wendler O, Marlee D, Hildick-Smith D, Young CP, Kovac J, Uren NG, Spyt T, Trivedi U, Howell J, Gray H, UK TAVI Steering Committee and the National Institute for 
Cardiovascular Outcomes Research. Transcatheter aortic valve implantation in the United Kingdom: temporal trends, predictors of outcome, and 6-year follow-up: a report from the UK Transcatheter Aortic Valve Implantation (TAVI) Registry, 2007 to 2012. Circulation 2015;131:1181-1190.

14. Paone G, Eng M, Kabbani LS, Borgi J, Peterson E, Novitsky B, Burroughs B, Wang DD, O’Neill WW, Greenbaum AS. Transcatheter Aortic Valve Replacement: Comparing Transfemoral, Transcarotid and Transcaval Access. Ann Thorac Surg 2018;106:1105-1112.

15. Petronio AS, De Carlo M, Bedogni F, Maisano F, Ettori F, Klugmann S, Poli A, Marzocchi A, Santoro G, Napodano M, Ussia GP, Giannini C, Brambilla N, Colombo A. 2-year results of CoreValve implantation through the subclavian access: a propensity-matched comparison with the femoral access. J Am Coll Cardiol 2012;60:502-507.

16. Damluji AA, Murman M, Byun S, Moscucci M, Resar JR, Hasan RK, Alfonso CE, Carrillo RG, Williams DB, Kwon CC, Cho PW, Dijos M, Peltan J, Heldman AW, Cohen MG, Leroux L. Alternative access for transcatheter aortic valve replacement in older adults: A collaborative study from France and United States. Catheter Cardiovasc Interv 2018.

17. Fröhlich GM, Baxter PD, Malkin CJ, Scott DJA, Moat NE, Hildick-Smith D, Cunningham D, MacCarthy PA, Trivedi U, Belder MA de, Ludman PF, Blackman DJ, National Institute for Cardiovascular Outcomes Research. Comparative survival after transapical, direct aortic, and subclavian transcatheter aortic valve implantation (data from the UK TAVI registry). Am J Cardiol 2015;116:1555-1559.

18. Ciuca C, Tarantini G, Latib A, Gasparetto V, Savini C, Di Eusanio M, Napodano M, Maisano F, Gerosa G, Sticchi A, Marzocchi A, Alfieri O, Colombo A, Saia F. Trans-subclavian versus transapical access for transcatheter aortic valve implantation: A multicenter study. Catheter Cardiovasc Interv 2016;87:332-338.

19. Chamandi C, Abi-Akar R, Rodés-Cabau J, Blanchard D, Dumont E, Spaulding C, Doyle D, Pagny JY, DeLarochellière R, Lafont A, Paradis JM, Puri R, Karam N, Maes F, Rodriguez-Gabella T, 
Chassaing S, Le Page O, Kalavrouziotis D, Mohammadi S. Transcarotid Compared With Other Alternative Access Routes for Transcatheter Aortic Valve Replacement. Circ Cardiovasc Interv 2018;11:e006388.

20. Auffret V, Regueiro A, Del Trigo M, Abdul-Jawad Altisent O, Campelo-Parada F, Chiche O, Puri R, Rodés-Cabau J. Predictors of Early Cerebrovascular Events in Patients With Aortic Stenosis Undergoing Transcatheter Aortic Valve Replacement. J Am Coll Cardiol 2016;68:673-684.

21. Nombela-Franco L, Webb JG, Jaegere PP de, Toggweiler S, Nuis R-J, Dager AE, Amat-Santos IJ, Cheung A, Ye J, Binder RK, Boon RM van der, Van Mieghem N, Benitez LM, Pérez S, Lopez J, San Roman JA, Doyle D, Delarochellière R, Urena M, Leipsic J, Dumont E, Rodés-Cábau J. Timing, predictive factors, and prognostic value of cerebrovascular events in a large cohort of patients undergoing transcatheter aortic valve implantation. Circulation 2012;126:3041-3053.

22. Maas EHA, Pieters BMA, Van de Velde M, Rex S. General or Local Anesthesia for TAVI? A Systematic Review of the Literature and Meta-Analysis. Curr Pharm Des 2016;22:1868-1878.

23. Debry N, Delhaye C, Azmoun A, Ramadan R, Fradi S, Brenot P, Sudre A, Moussa MD, Tchetche D, Ghostine S, Mylotte D, Modine T. Transcarotid Transcatheter Aortic Valve Replacement: General or Local Anesthesia. JACC Cardiovasc Interv 2016;9:2113-2120.

24. Auffret V, Puri R, Urena M, Chamandi C, Rodriguez-Gabella T, Philippon F, Rodés-Cabau J. Conduction Disturbances After Transcatheter Aortic Valve Replacement: Current Status and Future Perspectives. Circulation 2017;136:1049-1069.

25. Chamandi C, Barbanti M, Munoz-Garcia A, Latib A, Nombela-Franco L, Gutiérrez-Ibanez E, Veiga-Fernandez G, Cheema AN, Cruz-Gonzalez I, Serra V, Tamburino C, Mangieri A, Colombo A, Jiménez-Quevedo P, Elizaga J, Laughlin G, Lee D-H, Garcia Del Blanco B, Rodriguez-Gabella T, Marsal J-R, Côté M, Philippon F, Rodés-Cabau J. Long-Term Outcomes in Patients With New Permanent Pacemaker Implantation Following Transcatheter Aortic Valve Replacement. JACC Cardiovasc Interv 2018;11:301-310. 
26. Minha S, Waksman R, Satler LP, Torguson R, Alli O, Rihal CS, Mack M, Svensson LG,

Rajeswaran J, Blackstone EH, Tuzcu EM, Thourani VH, Makkar R, Ehrlinger J, Lowry AM, Suri RM, Greason KL, Leon MB, Holmes DR, Pichard AD. Learning curves for transfemoral transcatheter aortic valve replacement in the PARTNER-I trial: Success and safety. Catheter Cardiovasc Interv 2016;87:165-175.

27. Suri RM, Minha S, Alli O, Waksman R, Rihal CS, Satler LP, Greason KL, Torguson R, Pichard AD, Mack M, Svensson LG, Rajeswaran J, Lowry AM, Ehrlinger J, Mick SL, Tuzcu EM, Thourani VH, Makkar R, Holmes D, Leon MB, Blackstone EH. Learning curves for transapical transcatheter aortic valve replacement in the PARTNER-I trial: Technical performance, success, and safety. $J$ Thorac Cardiovasc Surg 2016;152:773-780.e14. 


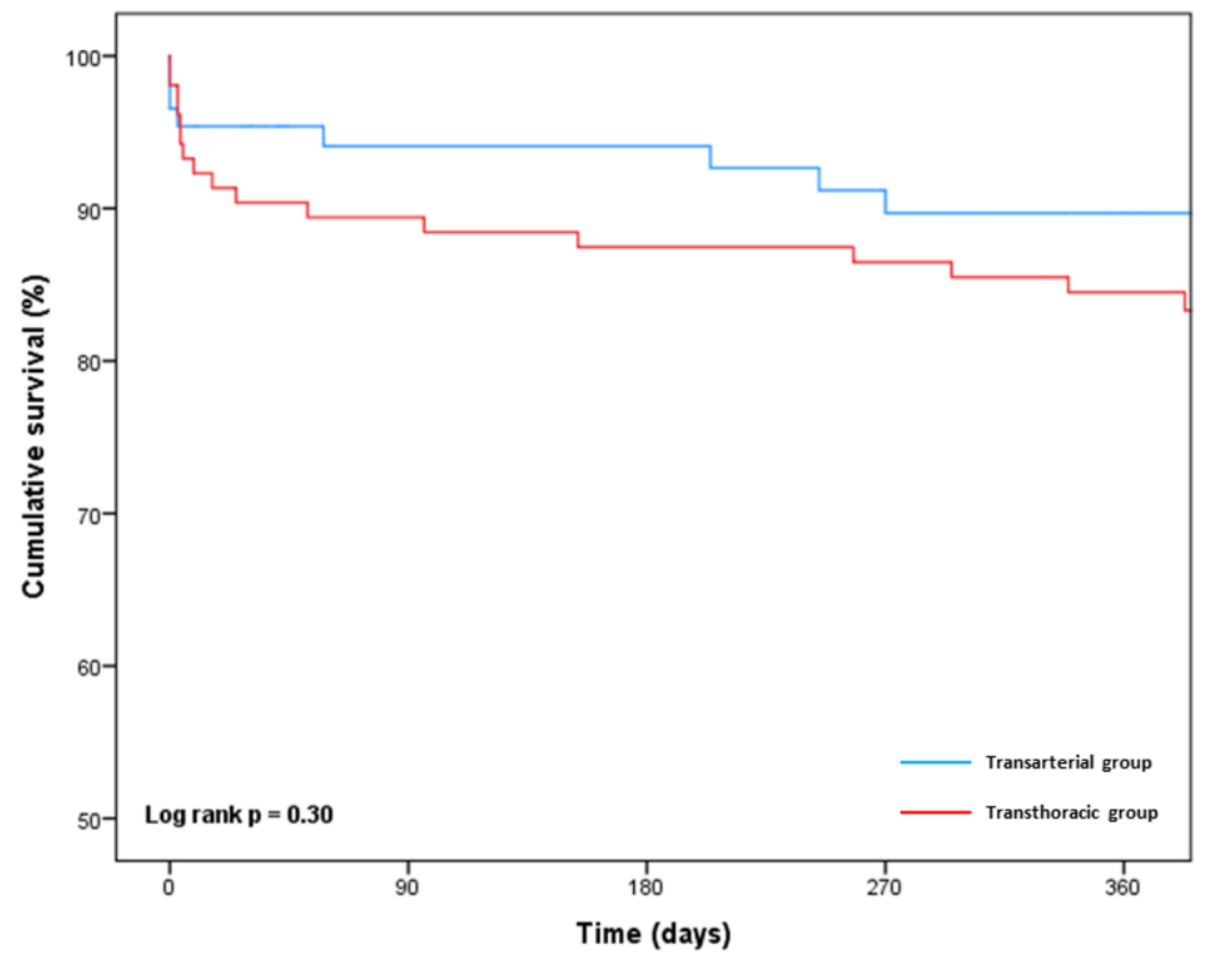

Patients at risk

Transarterial group

Transthoracic group
87

104

\section{1}

93
68

90
61

89
52

84

Figure 1 - Rates of all-cause mortality

Kaplan-Meier curves at 1-year follow-up for overall mortality according to the access site. 


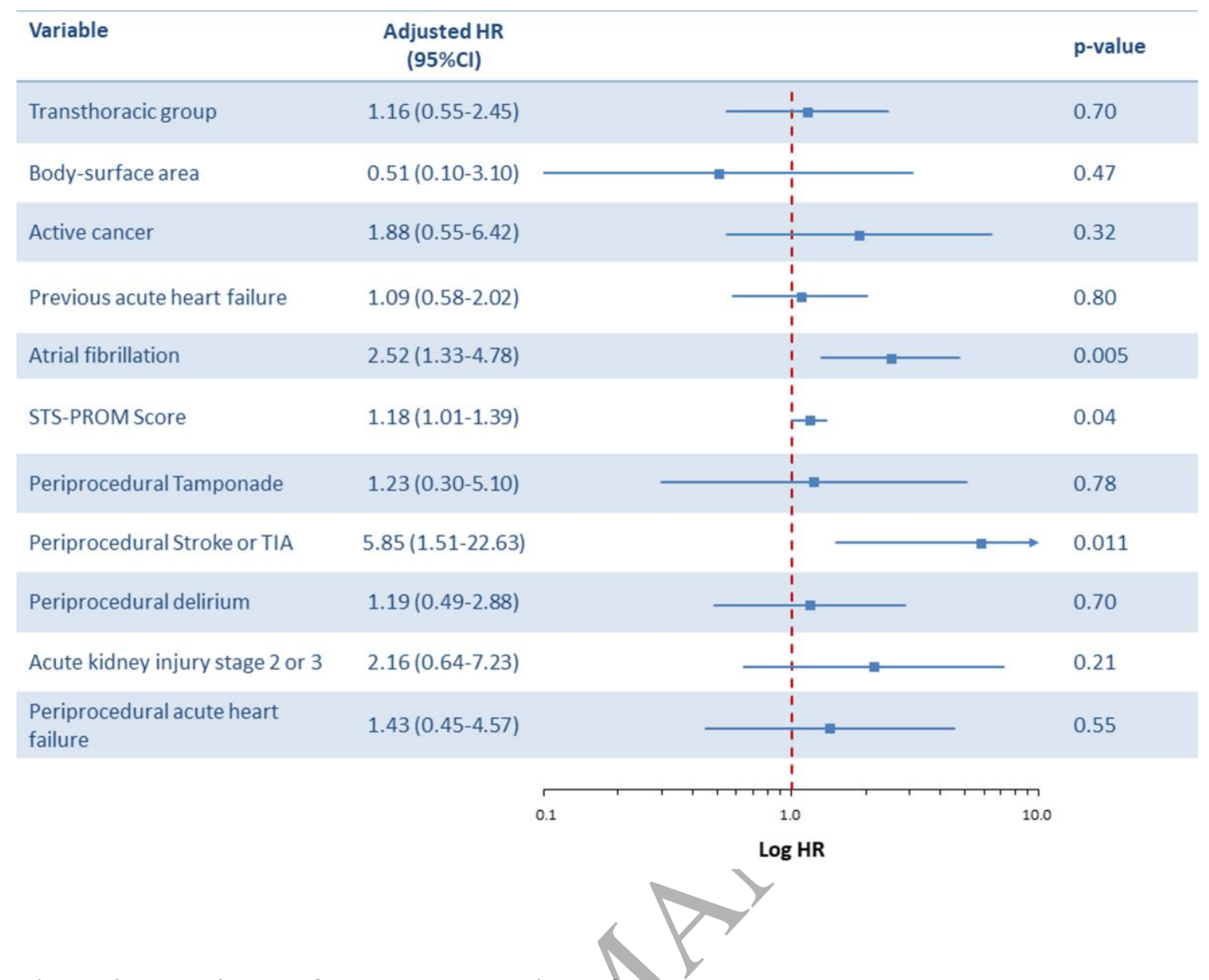

Figure 2 - Predictors of all-cause mortality at follow-up

Forest-plot showing the multivariable model for all-cause mortality, including all variables with a pvalue $<0.1$ in univariate analysis.

CI: confidence interval; HR; Hazard-ratio; STS-PROM: Society of thoracic surgeons predicted risk of mortality; TIA: transient ischemic attack.

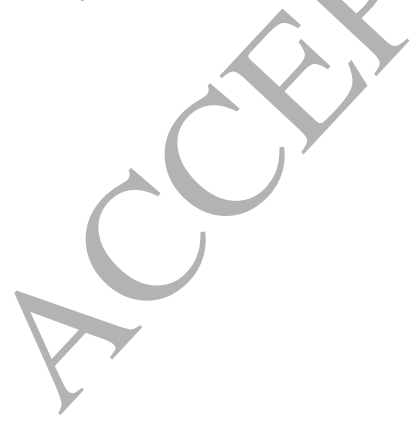




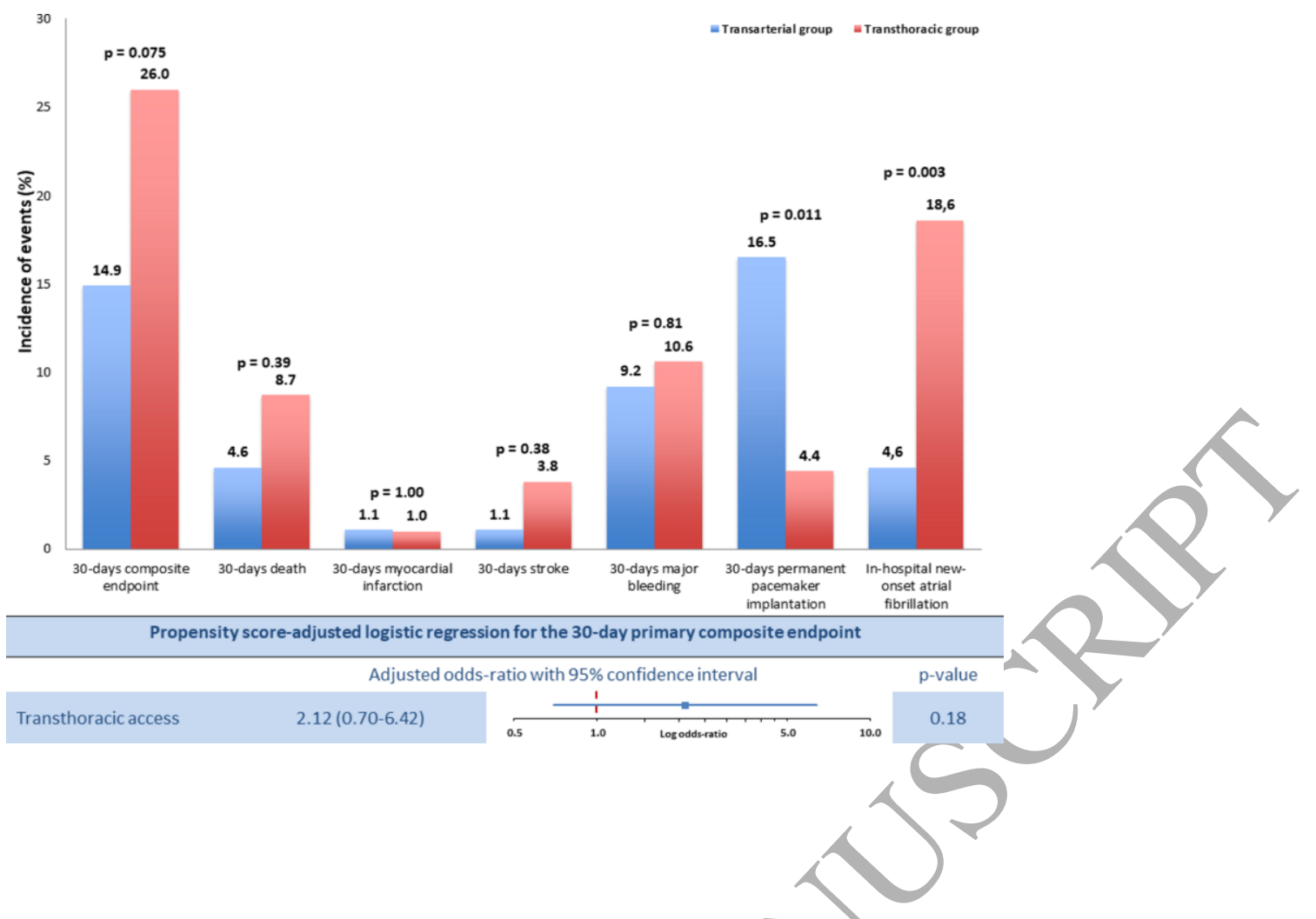

Figure 3 - In-hospital and 30-days outcomes according to TAVI approach

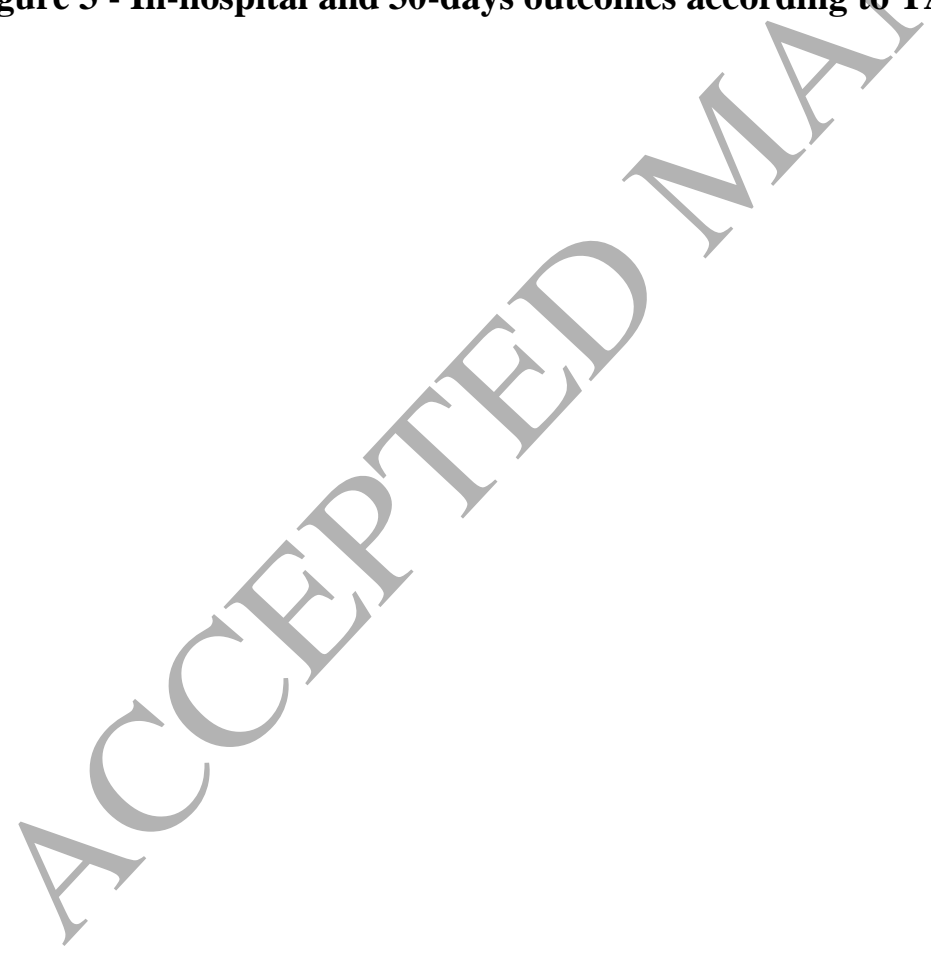


Table 1 - Baseline characteristics of the study population according to TAVI approach

\begin{tabular}{|c|c|c|c|}
\hline & $\begin{array}{c}\text { Transarterial } \\
\text { TAVI group } \\
(\mathrm{n}=87)\end{array}$ & $\begin{array}{c}\text { Transthoracic } \\
\text { TAVI group } \\
(\mathrm{n}=104)\end{array}$ & $\begin{array}{c}\mathrm{p}- \\
\text { value }\end{array}$ \\
\hline Age (years) & $79.3 \pm 6.7$ & $78.0 \pm 9.9$ & 0.60 \\
\hline Female sex & $35(40 \%)$ & $40(39 \%)$ & 0.88 \\
\hline Body-mass index $\left(\mathrm{kg} / \mathrm{m}^{2}\right)$ & $29.1 \pm 6.7$ & $26.4 \pm 4.8$ & 0.024 \\
\hline Body-surface area $\left(\mathrm{m}^{2}\right)$ & $1.83 \pm 0.21$ & $1.75 \pm 0.20$ & 0.025 \\
\hline NYHA class III or IV & $40(46 \%)$ & $51(49 \%)$ & 0.77 \\
\hline Previous acute heart failure & $31(36 \%)$ & $33(32 \%)$ & 0.65 \\
\hline \multicolumn{4}{|l|}{ Medical history } \\
\hline Hypertension & $62(71 \%)$ & $77(74 \%)$ & 0.75 \\
\hline Diabetes mellitus & $24(28 \%)$ & $18(17 \%)$ & 0.11 \\
\hline Coronary artery disease* & $42(48 \%)$ & $71(68 \%)$ & 0.008 \\
\hline Previous myocardial infarction & $12(14 \%)$ & $17(16 \%)$ & 0.69 \\
\hline Previous coronary artery bypass grafting & $15(17 \%)$ & $28(27 \%)$ & 0.12 \\
\hline Previous percutaneous coronary intervention & $22(25 \%)$ & $31(30 \%)$ & 0.52 \\
\hline Previous balloon aortic valvuloplasty & $8(9 \%)$ & $12(12 \%)$ & 0.64 \\
\hline Previous surgical aortic valve replacement & $7(8 \%)$ & $5(5 \%)$ & 0.39 \\
\hline Other cardiac surgery & $2(2 \%)$ & $3(3 \%)$ & 1.00 \\
\hline Atrial fibrillation & $39(45 \%)$ & $34(33 \%)$ & 0.10 \\
\hline Previous permanent pacemaker & $8(9 \%)$ & $13(13 \%)$ & 0.50 \\
\hline Cerebrovascular disease & $3(3 \%)$ & $19(18 \%)$ & 0.001 \\
\hline Previous Stroke/TIA & $8(9 \%)$ & $11(11 \%)$ & 0.81 \\
\hline Peripheral artery disease & $33(38 \%)$ & $46(44 \%)$ & 0.46 \\
\hline Active cancer & $3(3 \%)$ & $7(7 \%)$ & 0.35 \\
\hline Previous chest radiotherapy & $55(6 \%)$ & $8(8 \%)$ & 0.78 \\
\hline Hostile chest & - & $6(6 \%)$ & 0.03 \\
\hline Respiratory failure & $23(26 \%)$ & $27(26 \%)$ & 1.00 \\
\hline Renal failure & & & 0.64 \\
\hline Moderate & $39(45 \%)$ & $45(43 \%)$ & \\
\hline Severe & $3(3 \%)$ & $7(7 \%)$ & \\
\hline Dialysis & $2(2 \%)$ & $1(1 \%)$ & 0.59 \\
\hline Severe liver disease & - & $1(1 \%)$ & 1.00 \\
\hline Logistic EuroScore I & $12.0(7.0-21.0)$ & $14.9(9.7-23.0)$ & 0.053 \\
\hline Logistic EuroScore II & $3.4(1.9-5.8)$ & $3.4(2.4-6.9)$ & 0.22 \\
\hline STS-PROM Score & $3.1(2.2-4.8)$ & $3.5(2.4-4.9)$ & 0.18 \\
\hline \multicolumn{4}{|l|}{ Echocardiography } \\
\hline LVEF (\%) & $54.2 \pm 12.5$ & $54.0 \pm 13.3$ & 0.54 \\
\hline LVEF $<50 \%$ & $25(29 \%)$ & $27(26 \%)$ & 0.75 \\
\hline Aortic valve area $\left(\mathrm{cm}^{2}\right)$ & $0.74 \pm 0.16$ & $0.75 \pm 0.32$ & 0.56 \\
\hline Mean aortic gradient $(\mathrm{mmHg})$ & $49.0 \pm 15.7$ & $47.1 \pm 14.8$ & 0.60 \\
\hline Mean aortic gradient $<40 \mathrm{mmHg}$ & $20(23 \%)$ & $26(25 \%)$ & 0.87 \\
\hline Aortic regurgitation $\geq$ mild & $21(24 \%)$ & $34(33 \%)$ & 0.20 \\
\hline Mitral regurgitation $\geq$ mild & $23(26 \%)$ & $37(36 \%)$ & 0.21 \\
\hline Moderate or severe mitral stenosis & $3(3 \%)$ & $3(3 \%)$ & 1.00 \\
\hline Systolic pulmonary artery pressure $>60 \mathrm{mmHg} \dagger$ & $10 / 64(16 \%)$ & $17 / 79(22 \%)$ & 0.40 \\
\hline
\end{tabular}

*Coronary artery disease defined as previous myocardial infarction, or previous percutaneous coronary intervention, or previous coronary artery bypass grafting, or presence of at least one lesion $\geq 50 \%$ on the preoperative coronary angiogram.

$\dagger$ Systolic pulmonary artery pressure was measurable by echocardiography in 145 patients. 
Table 2 - Procedural characteristics of the study population according to TAVI approach.

\begin{tabular}{|c|c|c|c|}
\hline & $\begin{array}{c}\text { Transarterial } \\
\text { TAVI group } \\
(n=87)\end{array}$ & $\begin{array}{c}\text { Transthoracic } \\
\text { TAVI group } \\
(\mathrm{n}=104)\end{array}$ & $\begin{array}{c}\mathrm{p}- \\
\text { value }\end{array}$ \\
\hline Urgent procedure & $3(3 \%)$ & $4(4 \%)$ & 1.00 \\
\hline General anesthesia & $79(91 \%)$ & $104(100 \%)$ & 0.002 \\
\hline \multicolumn{4}{|l|}{ Approach } \\
\hline Sub-clavian & $73(84 \%)$ & - & \\
\hline Carotid & $14(16 \%)$ & - & \\
\hline Trans-aortic & - & $41(39 \%)$ & \\
\hline Transapical & - & $63(61 \%)$ & A \\
\hline Balloon-expandable valve & $23(26 \%)$ & $100(96 \%)$ & $<0.001$ \\
\hline Newer-generation valve* & $70(81 \%)$ & $44(42 \%)$ & $<0.001$ \\
\hline Valve type & & & $<0.001$ \\
\hline Edwards SAPIEN & $1(1 \%)$ & $27(26 \%)$ & \\
\hline Edwards SAPIEN XT & - & $30(29 \%)$ & \\
\hline Edwards SAPIEN 3 & $22(25 \%)$ & $43(41 \%)$ & \\
\hline Medtronic CoreValve & $13(15 \%)$ & $3(3 \%)$ & \\
\hline Medtronic Evolut R & $48(55 \%)$ & $1(1 \%)$ & \\
\hline Valve size $(\mathrm{mm})$ & & & $<0.001$ \\
\hline 23 & $15(17 \%)$ & $34(33 \%)$ & \\
\hline 26 & $27(31 \%)$ & $50(48 \%)$ & \\
\hline 29 & $39(45 \%)$ & $18(17 \%)$ & \\
\hline 31 & $3(3 \%)$ & $2(2 \%)$ & \\
\hline Number of implanted valve & & & 0.09 \\
\hline 0 & ( & - & \\
\hline 1 & $84(97 \%)$ & $103(99 \%)$ & \\
\hline 2 & $y-$ & $1(1 \%)$ & \\
\hline Fluoroscopy time (min) & $20.4 \pm 7.9$ & $13.0 \pm 6.3$ & $<0.001$ \\
\hline Dosimetry $\left(\mathrm{Gy} . \mathrm{cm}^{2}\right)$ & $82(55-132)$ & $82(55-128)$ & 0.99 \\
\hline Contrast volume (ml) & $140(110-199)$ & $140(108-177)$ & 0.66 \\
\hline Device success & $74(85 \%)$ & $99(95 \%)$ & 0.024 \\
\hline \multicolumn{4}{|l|}{ Perprocedural complications } \\
\hline Perprocedural death & $3(3 \%)$ & $1(1 \%)$ & 0.33 \\
\hline Valve embolization or ectopic deployment & $1(1 \%)$ & $2(2 \%)$ & 1.00 \\
\hline Conversion to open surgery & $2(2 \%)$ & $4(4 \%)$ & 0.69 \\
\hline Coronary obstruction & $1(1 \%)$ & - & 0.46 \\
\hline Tamponade & $2(2 \%)$ & - & 0.21 \\
\hline Annulus rupture & - & $1(1 \%)$ & 1.00 \\
\hline Left ventricular perforation & $1(1 \%)$ & $1(1 \%)$ & 1.00 \\
\hline
\end{tabular}

* Edwards SAPIEN 3 or Medtronic Evolut R 
Table 3 - Outcomes of the study population according to TAVI approach

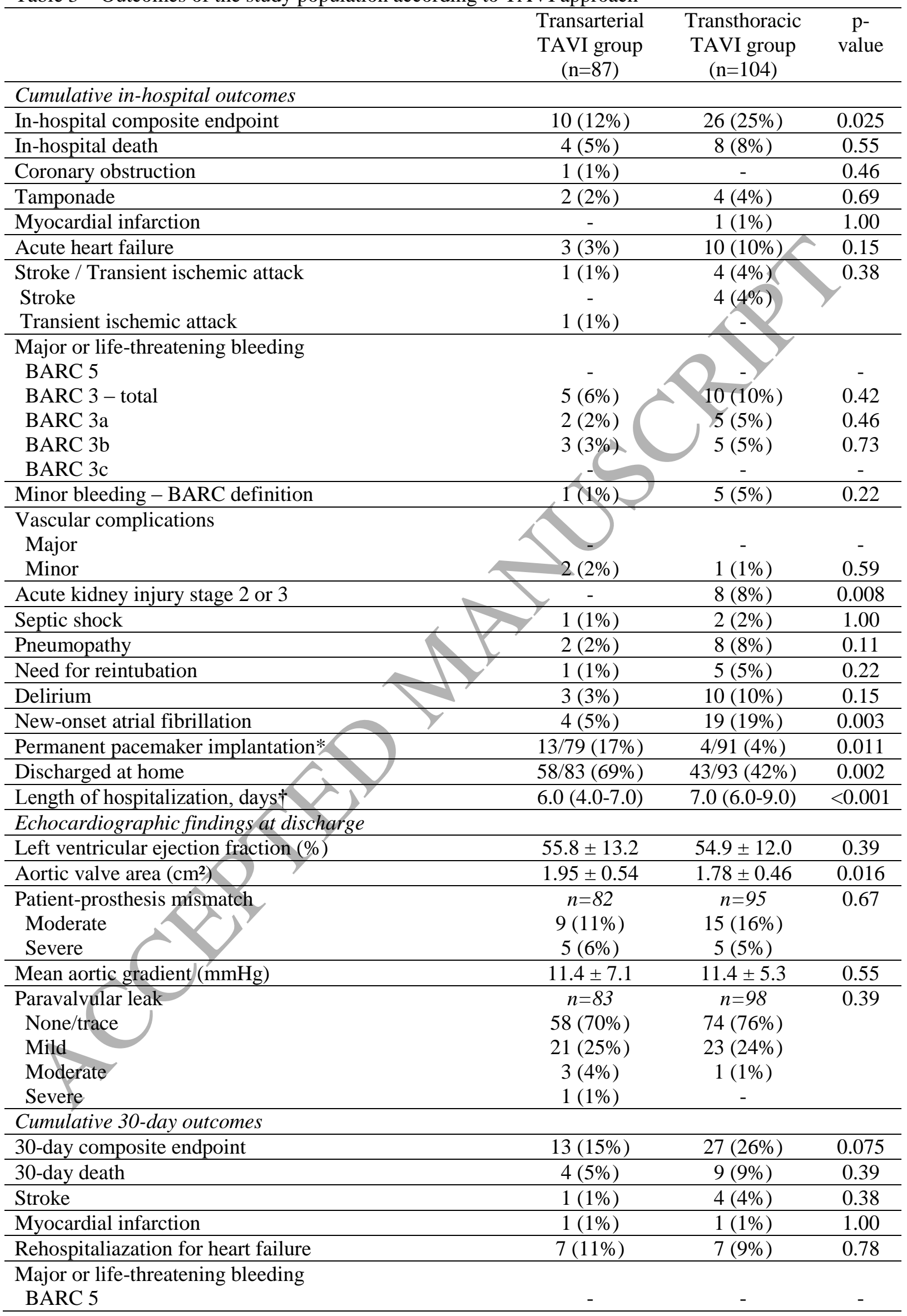




\begin{tabular}{lccc} 
BARC 3 - total & $8(9 \%)$ & $11(11 \%)$ & 0.81 \\
BARC 3a & $3(3 \%)$ & $5(5 \%)$ & 0.73 \\
BARC 3b & $5(6 \%)$ & $6(6 \%)$ & 1.00 \\
BARC 3c & - & - & - \\
\hline Major vascular complications & $1(1 \%)$ & - & 0.46 \\
\hline Permanent pacemaker implantation* & $13 / 79(17 \%)$ & $4 / 91(4 \%)$ & 0.011 \\
\hline
\end{tabular}

*Among patients without prior permanent pacemaker.

$\uparrow$ Among patients discharged alive from the hospital.

Composite endpoint : in-hospital occurrence of any of the following : death, need for open surgery, tamponade, stroke, major/life-threatening bleeding, stage 2 or 3 acute kidney injury, coronary obstruction, major vascular complications. 